\title{
GUEST EDITORS' INTRODUCTION TO CRIME AND PUNISHMENT FORUM
}

Since 1985, the Center for African Studies at the University of Florida (UF) has hosted an annual conference named for Gwendolen M. Carter, the second president of the African Studies Association (1958-59) and later emerita at the University of Florida. Carter conferences have had diverse themes-for example, migration and displacement, conservation and sustainability, architecture and design. In 2016, we organized a Carter conference on crime and punishment in Africa which we called "Topics of Discipline." We had initially wanted to examine the transnational traffics in drugs, ivory, and people, in part because we thought those topics would provide the most provocative discussion, and in part because we wanted to honor the memory of Stephen Ellis, a frequent visitor to UF whose work on crime inspired us and who passed away as we began to plan the conference.

The 2016 conference was interdisciplinary; historians, anthropologists, and political scientists presented conference papers that addressed the issues of global markets and global migrations and the punishments endured by political prisoners in colonial and post-colonial Africa. There were eighteen conference papers, many of which challenged conventional notions of crime and punishment. Five of the six articles in this forum are from that conference. The authors all challenge the category of crime in ways for which we were unprepared when we organized this conference. These articles in particular showed us how unstable certain categories became in twentieth-and twenty-first-century Africa; what separated crime from custom, for example, or magic from accumulation was not always clear to litigants and to the people who never set foot in a court of law. Status, many of these articles argued, was a matter of context and time and place. It could not always be defended in the home or in the courtroom. Each of these articles makes a significant contribution to a regional historiography, to be sure, but for our purpose what is most important about them is how they intervene in the study of crime in Africa.

African Studies Review, Volume 61, Number 3 (September 2018), pp. 53-55

(C) African Studies Association, 2018

doi:10.1017/asr.2018.86 
These articles divide into two groups, crimes with courts and crimes without courts. Daly, Keefer, and Shutt all address the complexities of courtroom testimony. Katrina Keefer's "Poro on Trial” [https://doi.org/10.1017/ asr.2018.6] provides a rich analysis of a single court case in the Sierra Leone Protectorate. Her close, contextualized reading of the testimony reveals the ways that a murder trial involving Poro and Leopard Men was not just about who killed, but also about who could live-and how comfortably they could do so-and exert influence in the early years of colonial rule. Allison Shutt's "Litigating Honor, Defamation, and Shame in Southern Rhodesia" [https:/ / doi.org/10.1017/asr.2018.27] provides a detailed analysis of two court cases, one in 1938 and the other in 1946. Both were trials for defamation, both set precedents, but taken in sequence, Shutt demonstrates with great clarity how literate Africans learned to use courtroom proceedings to their own advantage. Questions of status and family history could easily be translated into vocabularies understood by lawyers and magistrates. By 1946, Africans had used legal proceedings to construct a category by which to defend their status and prestige, the idea of professional honor, of the respect and subservience due a clerk or a clergyman. By contrast, Samuel Fury Childs Daly's "'Hell was let loose on the country" [https://doi.org/10.1017/asr.2018.41] takes for his analyses many court cases in Biafra. If legal proceedings in Sierra Leone in 1913 took place in the shadow of slavery, Biafra's courts were under the shadow of Grey's Inn and legal precedent already established in the Anglophone world, by lawyers trained in Britain and India. As defendants and prosecutors struggled to address the impact of the flow of guns into a country with an untrained and poor but entrepreneurial army, prosecutors and judges opined and ruled on the place of self-defense in national defense and debated whether rulings made in peacetime were applicable in times of war. For all the Africanist scholarship on courtroom testimony, Daly gives us the voices of judges speaking with great erudition in appalling conditions.

The other papers here tell of the world of crime with no courts. Steinberg, Scheele, and Musoni, describe places and crimes where there is no accountability in modern, legal terms. Jonny Steinberg's "Xenophobia and Collective Violence in South Africa" [https://doi.org/10.1017/asr. 2018.56] is a reflection on the killings of Somalis in South African townships. Steinberg rigorously avoids ideas of othering and scapegoating, and instead addresses the seemingly un-natural pattern of accumulation of Somali shopkeepers. When one Somali is murdered and his spaza shop burned to the ground, another comes to build a new shop on that very site. No one is accountable for these murders, although Steinberg makes it clear that it is not only the killings of Somalis that go un-investigated in South Africa's townships. There is no punishment here, only crime. Judith Scheele's "Ravens Reconsidered," [https://doi.org/10.1017/asr.2018.34] about raiding and theft in Northern Chad, is a world away, but it raises questions adjacent to those posed by Steinberg. When is a crime not a crime? When is it normal if not natural? If young men customarily raid 
cattle-maybe to get bride wealth, maybe to act the way young men are supposed to act-is it a crime in twenty-first century Chad? Can such customary actions be criminalized? Scheele understands that western vocabularies of property and right and wrong are not always an exact fit with herders' realities. The functionalist underpinnings of social science for Africa do not translate well to the unpoliced outposts of Sahelian states. New categories of analysis and indeed of property are needed. As one of her informants put it, stealing a beautiful camel from the bush is not the same as stealing something from someone's house; it is not hidden. Francis Musoni's “The Ban on 'Tropical Natives' and the Promotion of Illegal Migration in Pre-Apartheid South Africa" [https://doi.org/10.1017/asr.2018.73] shows how irrelevant laws regarding the movement of peoples can be. In 1913, South Africa made it illegal for employers to recruit labor from Southern Rhodesia, Nyasaland, and Portuguese East Africa. There were many reasons for this, none of which were very convincing, but even in the short run it did not matter. Even before the end of World War I, the Chamber of Mines sought to be excused from the ban, but even the number allowed under the exemption was not sufficient to its needs. Unlicensed recruiters brought in illegal migrants, and some mine owners asked their employees to recruit workers for them when they returned to Nyasaland or Mozambique, resulting in a joining of labor recruitment and illegal migration. The ban was lifted in 1928, but this did little more than make a set of practices legal: South-central Africa had already been reconstructed as a terrain of illegal migrants, men jumping rather than crossing borders. Crimes and courts did not matter, nor did the meaningless fines paid by a few hapless employers: the needs of South African capital, especially the voracious mining industry, trumped laws and bans and prohibitions. Precedents and policies were made in the boardroom or the mine manager's office; they were not made in the courts. Perhaps more than any other author, Musoni reminds us that the lawlessness and lack of accountability we condemn in contemporary Africa has its roots in older forms of governance on the continent.

Taken together, these articles offer not only a way to think about the complexities and contradictions of crime in colonial and post-colonial Africa, but also a lens through which to see the complexities and contradictions of redress for wrongs as well.

\author{
Luise White \\ University of Florida \\ Gainesville, $F L$ \\ lswhite@ufl.edu \\ Todd Leedy \\ University of Florida \\ Gainesville, FL \\ tleedy@ufl.edu
}

